\title{
Prophetic preaching in the contemporary context of South Africa
}

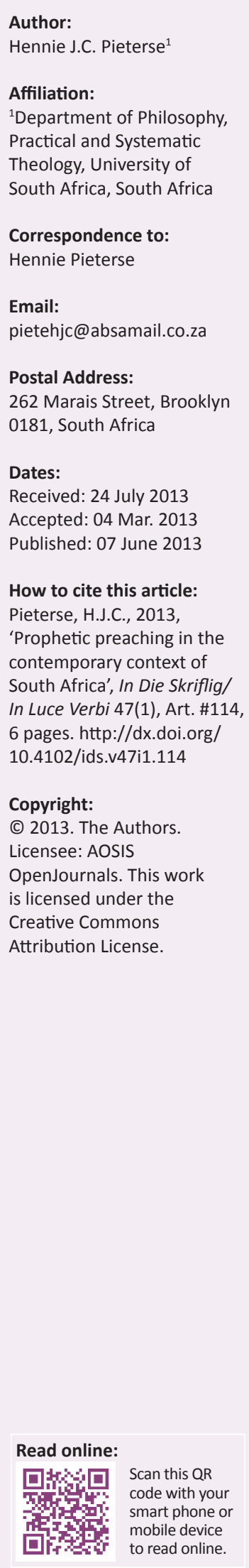

In South Africa we have a great legacy of prophetic preaching with preachers such as Desmond Tutu. Since the new dispensation, however, we are confronted today with a new situation of injustice and exclusion: the massive poverty amongst about $50 \%$ of the population. This article discusses the conditions for prophetic preaching in the current context of South Africa, which are a clear understanding of the poverty situation and solidarity of the church with the poor, a good understanding of prophetic preaching as a specific type of preaching, as well as the support of the congregation, the churches and the ecumenical church for prophetic preaching.

Profetiese prediking in die huidige konteks van Suid-Afrika. Met predikers soos Desmond Tutu het ons 'n goeie erfenis van profetiese prediking in Suid-Afrika. Sedert die nuwe bedeling word ons egter met 'n nuwe situasie van ongeregtigheid en uitsluiting gekonfronteer: die massiewe armoede van ongeveer $50 \%$ van die bevolking. Hierdie artikel bespreek die voorwaardes vir profetiese prediking in die huidige konteks van Suid-Afrika: 'n duidelike begrip van die armoedesituasie en solidariteit van die kerk met die armes, 'n goeie begrip van profetiese prediking as 'n spesifieke soort prediking, asook die ondersteuning van die gemeente, die kerk en die ekumeniese kerk vir profetiese prediking.

\section{Introduction}

With excellent preachers like Desmond Tutu, we have a great legacy of prophetic preaching against apartheid (cf. Pieterse 2001). The injustice caused by apartheid has been resolved in the new dispensation in 1994 with a constitution in which human rights are safeguarded, and a democratically elected government has been appointed. A new situation of injustice is confronting us today - the unbearable poverty of about $50 \%$ of the population, according to prof. Carel van Aardt of the Bureau of Market Research at the University of South Africa (Strydom 2009). In this article I discuss the contemporary South African context of massive poverty and self-enrichment by the elite, which to my mind challenges preachers today to preach prophetically in our context. This phenomenon of massive poverty puts the poor in our country in a situation of injustice and exclusion from the rest of the South African population (Burger, Louw \& Van der Watt 2010:62). The practice of preaching this inhuman situation creates a problem for the preacher. Should we preach prophetically on the shortcomings of the present social order in such a context (Tisdale 2010:9)? This problem falls out in three questions:

- What circumstances challenge a preacher to take a prophetic stance in society?

- What is prophetic preaching?

- Do prophetic preachers need the support of a church community or are they lone rangers?

The book by Tisdale (2010) focuses our attention again on the need for prophetic preaching. The South African context differs from the context of the United States. Therefore we must address our context with a specific South African approach. As an answer to the research questions above, I will investigate the conditions that qualify prophetic preaching in this new context in our country. That is also the goal of this article: to find the conditions in which prophetic preaching in an unjust and undignified situation would be necessary. First the contemporary South African context of poverty against the self-enrichment of the elite will be described, followed by a description of prophetic preaching and a discussion of the need for church support for this type of preaching.

\section{Suffering of the poor in the contemporary South African context}

When the new democratic government took office with Nelson Mandela as president, all South Africans experienced a feeling of great liberation. Our hopes were high for a new dispensation of freedom for everyone, and we were ready to solve the problems of the country and create a 
dignified and happy life for all. Many poor people thought that the government would look after them, but this is not what happened. The current (2012) social grants serve 15.6 million people out of the population of over 45 million. These are assigned to the elderly poor who do not have a pension, children of poor mothers until they turn 18, orphans, disabled people, poor foster parents and poor caregivers of old and frail people (Claasen 2012; Laubscher 2012). The expenditure in the budget of the state for social grants in 2012 is $11 \%$ of the total budget; an expenditure that is gradually reaching its limits of being affordable. The social grant for a poor family of four (total of the separate grants of the family members), according the Minister of Finance's 2012 budget speech, is R3940 per month or R47 280 per annum (Laubscher ibid). Unfortunately these social grants do not always reach the poor. According to the minister of social development, ms Bathabile Dlamini in a statement in parliament, R41 million disappeared in recent years (August 2009 to December 2011) as a result of corruption by officials who work with the distribution of social grants (Ferreira 2012). Corruption with regard to social grants denies the poor of our country food, their most basic need for survival.

The problem is that these social grants hardly provide for the most basic needs for survival of the poor. In our context, more than $50 \%$ of the adult population still earns less than R50 000 per annum, according to the research of prof. Carel van Aardt of the Bureau of Market Research at the University of South Africa, communicated in a press release (Strydom 2009). South Africans who earn less than R50 000 a year can usually not break through the glass ceiling to move up to a better income. These people are either unemployed, earn a small income in the informal sector or are dependent on social grants (Strydom ibid). The poverty line is a cutoff point, above which people can maintain a minimum standard of living, but below which it is not possible or very difficult (Pieterse 2004:30). In our context in 2012, we can deem an income of less than R50 000 per annum as beneath the poverty line. In the year 2000 , about $50 \%$ of the population of South Africa lived beneath the poverty line. Since then there has been an increase in poverty (Burger et al. 2010:66). Although the government has involved more people in social grants, the gap between rich and poor is increasing - the rich elite is getting richer and the poor masses are getting poorer. They are excluded from the wellbeing of their countrymen and experience injustices against them (cf. Burger et al. 2010:62; cf. Van Aarde 2012). Compared to the poor who are trapped in poverty and cannot move to a higher income, we have those in South Africa who earn top incomes (more than R750 000 per annum); a number that has grown by $52 \%$ around 2008 and 2009 . These top earners are either government workers, workers in the private sector or self-employed, according to prof. Carel van Aardt (Strydom ibid). These figures show the serious gap between the poor and the rich in this country.

Wepener and Cilliers (2010) listed more factors than just the lack of income in their description of poverty. They call it a diverse definition in the light of their understanding of social capital. Against the feeling of a sense of belonging and the formation of trust and identity, poverty could be described as exclusion. The poor are denied their identity as human beings and members of society. The poor have a lack of useful civic skills (Wepener \& Cilliers 2010):

Poverty could indeed be described or defined as: a state of affairs where the absence of material resources, lack of space to enable the formation of trust and identity, as well as the loss of civic skills and collaborative opportunities to further real transformation, impact negatively on one another in a seemingly unstoppable and escalating spiral. (p. 420)

This situation is even more serious when we compare it with the rich elite and the new rich elite (government workers and some self-employed people, of which many are tenderpreneurs). In the South Africa of today we are still confronted with the huge divide between high and low, or no income. Buffel (2010) describes it aptly:

... the South African situation is ... marked by destitution, hunger, homelessness and overcrowding, illiteracy, the HIV and AIDS pandemic as well as other ills associated with poverty such as crime and violence. These factors paradoxically co-exist with affluence. (p. 36)

The unequal distribution of wealth is expressed by the Gini coefficient, with 0 representing total equality and 1 total inequality (Pieterse 2004:51). In 2000, South Africa scored 0.59 . In 2009, nine years later, we scored 0.67 , which shows that the income gap between rich and poor is increasing (Strydom 2009).

Unemployment is a perennial problem in South Africa. Since 1994 , it has been shifting between $29 \%$ and $25 \%$ of the population who are able to work (Pieterse 2004:38). There is a relation between finding a job and the level of primary and secondary school education received and opportunities available for tertiary education. The problem is that our state schools are not functioning well. The ministries for poverty and care of the Dutch Reformed Church (NG Kerk) and the Uniting Reformed Church organised a conference on poverty and education in Bellville on 13 and 14 March 2012. There were people from all relevant walks of life in South Africa: government ministers, school commissions, labour unions, teachers, a commercial institute and a wide variety of university professors. The picture that emerged from the conference was a bleak one for education at our state schools). There is enough money to service our education system - R207 billion for 2012. But compared to 40 countries of similar economies and development levels, the quality of our education for the poor is amongst the bottom 10 out of the 40 countries. The quality of South African education in the state schools is worse than that of Malawi, Lesotho, Mozambique, Namibia, Uganda, Zimbabwe, Kenya and Swaziland (Manuel 2012).

Our educational system at the primary school level scores low compared with the education systems of the rest of the African countries south of the Sahara. From a list of 14 countries, South Africa lies ninth). Botswana is first, Kenya is second and Mozambique is sixth on the list. South Africa is just above Swaziland (Rademeyer 2011). As long as this 
situation continues, poverty will continue. Better education is a vital instrument in the fight against poverty. Preachers should inform themselves on this issue and sensitise members of the congregation in their sermons.

Homelessness is also a perennial problem and squatter camps are growing at the edges of towns and cities. In many of these squatter camps and in many townships there is no service delivery for water, sewerage and electricity. In the last few years, protests about poor service delivery in the townships have become more and more expressive. After 18 years of democracy, a new situation of poverty has developed and the service delivery protests by the poor at many places in the country are a symptom of this new situation where people are still experiencing injustice and social-economic exclusion in their lives (Manala 2010).

\section{A qualitative research project on the experience of poverty in townships with informal housing}

At the beginning of 2011, I conducted qualitative structured interviews with Black young people waiting in a queue at organisations who want to provide training for jobs at Mamelodi (Tshwane) and Zamdela (Sasolburg). My field workers asked them to voluntarily fill in the answers to the questions in the open spaces of the structured interview schedule. We started at the back of the queues and stopped the data collection when we received 15 respondents' replies at Mamelodi and four at Zamdela, where there was a short queue. Fifteen respondents is usually enough in a qualitative structured interview research project to get a picture of people's experiences and views, which they express in their own words in their written answers (Nieuwenhuis 2007:79).

Although this research project is about the poor's experiences of poverty, two questions in the structured schedule pertain to the issues of the social analysis by Manala (2010). The particulars of the respondents participating in the survey follow.

\section{Mamelodi (Tshwane) group}

There were nine male and six female respondents. The majority was unemployed (13) and two were employed. All the male respondents were unemployed. The average age was 24.8 years.

I report on two questions in the analysis of the responses from the Mamelodi respondents.

\section{The experience of being unemployed or receiving a meagre income}

The question was phrased as: 'Your experience of joblessness or receiving a meagre income? Please write.'

Eight out of the 15 respondents named bad housing or shelters and lack of food as the most severe experiences of their situation of poverty.
Respondent 8 (male, 35 years old, unemployed) wrote: 'I am experiencing difficulties because I am unemployed. It is hard for me to get food or to get a better house. Sometimes I sleep with an empty stomach ... My parents are suffering because they do not receive any income ... six members of our family share one room.'

Respondent 4 (male, 23 years old, unemployed) wrote: 'It is hard to live a jobless life, because everyone needs food and shelter to survive. If you don't work you can become a thief.'

Respondent 3 (male, 23 years old, unemployed) wrote: 'It is difficult ... receiving $[a]$ meagre income due to the fact that I am on foster care [that] does not cover my basic needs to survive.'

Poverty also destroys a young man's dreams: Respondent 7 (male, 22 years old, unemployed) wrote: 'Being jobless is a big problem, because you can't have ... thing $[s]$ you need, more especially food, $[a]$ car or even [the] house of your dreams.'

Respondent 6 (male, 35 years old, unemployed) wrote: '[Joblessness] is discouraging, especially when seeing other people earning lots of money but not doing their job properly.'

\section{Protests with regard to service delivery in the townships and squatter camps}

The question was phrased as: 'Why do people protest against weak, or no service delivery in the townships and squatter camps? Please write.'

Out of the 15 respondents, 13 named promises for better service delivery not being kept.

Respondent 2 (male, 29 years old, unemployed) wrote: 'Politicians promise poor people proper service delivery when they need their votes during elections, but after they get what they want they disappear. That causes people to protest.'

Respondent 9 (female, 20 years old, unemployed) wrote: 'The reason [why they protest] is because the political parties in our country promise to deliver those services in exchange for votes, so they feel unjustified.'

The responsible officials and councillors of the municipality do not care.

Respondent 11 (female, 28 years old, employed) wrote: 'Because people who are responsible for the service delivery in the townships and squatter camps ... do not do their jobs; they always sit in their offices and push their own agendas using the government resources, and they don't even care because they don't stay in the township or squatter camps; they stay in the suburbs.'

Respondent 1 (male, 23 years old, unemployed) wrote: 'Because they have sent a lot of memorandums to the local councillor, but they $[d o]$ not receive [a single] response ... I mean, the local councillor is there because of these people. The 
worst part is [that] during the local votes they promise people a whole lot more and service delivery, but then again, they only care [about] our votes; they don't really care about us.'

RDP houses are given to people who do not qualify.

Respondent 3 (male, 23 years old, unemployed) wrote: 'The protest is caused by the people who occupy houses while they do not qualify for those housing. The administration, especially in the squatter camps, is very bad.'

\section{Zamdela (Sasolburg)}

There were two male and two female respondents and all four were unemployed. The average age was 24 years. The respondents were listed from respondent 16 to respondent 19.

In the analysis of the Zamdela control group, I looked for differences and similarities in the responses on the two questions compared to the Mamelodi group.

\section{The experience of being jobless or receiving a meagre income}

All four respondents named bad housing or shelters and lack of food as the most severe experiences of their situation of poverty.

Respondent 17 (female, 21 years old, unemployed) wrote: '[The] experience of being jobless is that food is too expensive and not affordable.'

Respondent 16 (male, 27 years old, unemployed) wrote: 'Yes, I am jobless and ... receiving food from my parents.'

\section{Protests with regard to service delivery in the townships and squatter camps}

Three out of four respondents named promises for better service delivery not being kept.

Respondent 17 (female, 21 years old, unemployed) wrote: 'People are protesting because they are not satisfied [with] the way things are going in our community. The empty promises that the municipality and the government are giving to the community and the nation.'

Respondent 18 (male, 27 years old, unemployed) wrote: 'Because our government likes to make promises to our people, but they don't fulfil it.'

The responsible officials and councillors of the municipality do not care.

Respondent 16 (male, 27 years old, unemployed) wrote: 'In our township they don't care about people; they [only] look after themselves.'

The analysis of the two groups' responses on the two questions show that there are generally no differences in their experiences and views. As young people living in different townships and in informal housing, they experience joblessness and poverty in the same way (cf. Pieterse 2012b).
Corruption by officials who are administering the funds for services to the poor deepens their experience of misery. Nelson Mandela condemns this phenomenon of corruption (Mandela 2010):

But history never stops to play tricks even with seasoned and world famous freedom fighters. Frequently, erstwhile revolutionaries have easily succumbed to greed, and the tendency to divert public resources for personal enrichment ultimately overwhelmed them. By amassing vast personal wealth, and by betraying the noble objectives which made them famous, they virtually deserted the masses of the people and joined the former oppressors, who enriched themselves by mercilessly robbing the poorest of the poor. (p. 406)

Desmond Tutu also takes a strong prophetic stance on this issue in his latest book (Tutu 2011):

How utterly despicable and how thoroughly disillusioning that there have been officials called 'civil servants' who have proved to be neither civil nor servants, who have actually robbed the most needy through pocketing their social welfare grants. The victims have been the elderly, robbed of their desperately needed pensions, often the only income in homes where those traditionally the breadwinners, are unemployed. Such corrupt persons have shown they are devoid of a sense of shame and common decency. (p. 202)

In this contemporary context of poverty, the church and its preachers face a great challenge. As disciples of Jesus we are obliged to side with the poor. In Matthew 25:31-46 Jesus calls us to identify with the poor as he did and care for them. Furthermore, this text teaches us that he is also present today in the need of the poor, and in caring for them we care for Jesus himself. Therefore, the first condition for prophetic preaching in such a situation is solidarity with the poor. One has to side with them and experience their life situation existentially (Pieterse 2004:85-87).

\section{A description of prophetic preaching}

My homiletic theory regards preaching in its very essence as situational and topical. It seeks to communicate God's word to people in their particular context. It is impossible to ignore the poor in our country and merely preach about faith as a private, spiritual affair. Preachers approach the Biblical text from their own context (Pieterse 2004:80-82; Immink 2010:13). A second step is to evaluate societal notions with an approach of ideological suspicion on the basis of poor people's understanding of society; beware of the dominance of the values of the upper middle class and the rich in a society. This includes religious, ecclesiastic and theological notions. Then, in the next step, we do exegesis (the design of the meaning of the text) for preaching in the context of the first hearers of the text whilst we keep our own context in mind in our hermeneutical activity. In this confrontational dialogue between the reader and the text, the text criticises our own understanding and presuppositions of our own context and opens up new possibilities of human existence in this context. The preacher receives the 'self' of the text, tantamount to admitting a new 'self' into his or her own life (Ricoeur 1976:99-105). The process of understanding the message of the text for our situation opens up new worlds to the preacher and the congregation; honing and refining 
their prejudices and biases, putting them in a new light, and changing us to see new light and new hope in a context of suffering; in short, God's vision for the contemporary situation. The dynamics of the work of the Holy Spirit become operative when we read the text and our context in prayerful meditation, with open minds and in a deeper space of covenantal contact with God in the homiletic process (cf. De Wet 2011).

Although we can say that all preaching is prophetic in general terms, prophetic preaching in a situation where a part of the society or community is experiencing injustice and exclusion, is a distinctive type of preaching (cf. Tisdale 2010:4). It is not the same kind of preaching as on a general Sunday according to a lectionary, or the church calendar (Advent, Christmas, Lent, etc.), or preaching as teaching, or on a special day. Prophetic preaching in a context of injustice and exclusion reaches over the borders of a single congregation - it has a message for the ecumenical Christian church, the broader society and the government. Prophetic preaching is contextual. Its approach is from the angle of the poor, hence in terms of their need for justice and righteousness. Preachers' hermeneutical orientation should be such that they respond to their exegesis interpretatively within the crisis of the prevailing situation of poverty. This calls for critical, creative thought in order to prophetically proclaim God's words in this new social context:

Profetiese prediking is ' $n$ prediking waarin ' $n$ geroepe getuie spreekbuis word van die lewende handelende God; wat optree in ' $n$ bepaalde krisisgelaaide konteks met ' $n$ krities-kreatiewe woord waardeur verlede en hede, tradisie en krisis evangelies herinterpreteer word in terme van 'n nuwe beloftewoord sodat dit nuwe verbeeldingryke lewensmoontlikhede en alternatiewe bied. By die profetiese inhoud pas 'n profetiese styl en retoriek: naamlik die van waagmoed en pastorale bewoënheid en nabyheid binne die kring van skeppende gemeenskappe van geloof. [Prophetic preaching is preaching in which a summoned witness becomes a mouthpiece of a living, acting God; a witness who acts in a given crisis-charged context with a critical, creative word in which past and present, tradition and crisis are evangelically reinterpreted in terms of a new promise so as to offer new, imaginative existential possibilities and alternatives. The prophetic content calls for a prophetic style and rhetoric; a style of boldness and pastoral compassion and closeness within the circle of creative communities of faith.] (Müller 1996:55, [author's own translation])

Hermeneutical translation (from one context to another) for the purpose of a prophetic sermon is an interpretation of the text in such a way that its intention is not lost. Imaginative, relevant translation of a text for a sermon means inquiring hermeneutically into the intention of the text and then allowing it to progress dynamically to a new, liberating message in the present-day context in order to open up new existential possibilities: the scripturally fixed words of the text become a Word event all over again; a speech act with new, relevant meaning for the congregation's situation (Long 2005:22).

Prophetic preaching is preaching based on biblical texts revealing God's vision for justice, peace and equality in our world, and preaching that addresses public and social concerns (Tisdale 2010:3). It voices God's passion for others, proclaims the promises of God and points the way to new possibilities and hope (Tisdale ibid:5). As West (2004) pointed out:

Prophetic witness calls attention to the causes of unjustified suffering and unnecessary social misery. It highlights personal and institutional evil, including the evil of being indifferent to personal and institutional evil. (p. 114)

Some listeners in affluent congregations in South Africa do not want to hear sermons on poverty. It could be a result of a feeling of guilt as well as the feeling that they do not know what do about it. In my research project of a grounded theory analysis of sermons on Matthew 25:31-46 in Dutch Reformed (NG Kerk) and Uniting Reformed congregations in eight provinces, the sermons on poverty are in many congregations combined with a great variety of projects by congregational members directed to the poor. ${ }^{1}$ Where this happens, the church members participate with enthusiasm.

The liturgy plays a crucial rule of which the sermon is a part. In the liturgy, God's liberating deeds are celebrated through commemoration. In the Christian church, the deliverance by the Messiah, Jesus Christ, is commemorated in the liturgical celebration of Holy Communion. In this way each participant in the liturgy of Holy Communion shares in Christ's salvation time and again, and has an expectation of deliverance from suffering in the work of Christ through his Spirit. The relevance and promises of God's word in preaching are thus kept alive by means of commemoration and expectation (cf. Bohren 1974). Desmond Tutu's prophetic preaching was directed by his belief that Jesus has overcome evil on the cross (Pieterse 2001:49-50). Perhaps we should revisit the prayers and songs in the liturgy during the struggle against apartheid (De Gruchy 1986):

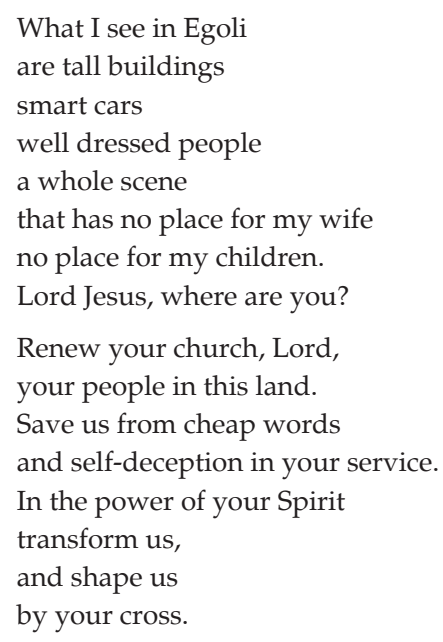

Every preacher should discerned the content of our prophetic preaching in contemporary South Africa in the specific context of the congregation. General issues that can be addressed are corruption by officials administering state funds, maladministration of state funds and unskilled people in crucial positions in the private sector who cannot do the job, but are there because they are ANC cadres due to the policies by the government to redeploy people to other positions after they are found guilty of corruption or maladministration in a previous government position. All 1.For a typology of these projects, see Pieterse (2012a). 
these things deprive the poor from their rights and bereave them of hope for a better life. Some of the results are a meagre functional education system in state schools and a meagre functional medical system in state hospitals and clinics.

An important issue is the malfunctioning of education in the state school system as described above. Preachers should inform themselves on this issue and sensitise members of the congregation in their sermons. The churches must also address the government on a continued basis to do something about the situation. Preachers should constantly take note of the news every day and follow issues and developments that can harm the poor and the citizens of South Africa.

But, there is also good news: we can play a positive role in this context of poverty. Preachers can sensitise members of the congregation to participate voluntarily in congregational projects of charity and empowerment of the poor as mentioned above (cf. Pieterse 2012a).

This distinctive type of preaching is a second condition for prophetic preaching.

\section{The church and the ecumenical faith community must support prophetic preaching}

The South African Council of Churches, most churches in South Africa, and the ecumenical faith community all over the world supported Desmond Tutu's prophetic preaching. He was a pastor who lived close to his oppressed people and he had no political motivations or ambitions. In our contemporary situation, the prophetic preacher also needs a prophetic faith community. His or her congregation must be sensitised to become a prophetic faith community (cf. Corbett \& Smith 1980). The South African Council of Churches has already made strong statements in the past, criticising the government on its handling of the poor. So did Tutu, as we have seen. But it is important that the local church of a preacher will support him or her in such relevant preaching when issues of poverty and the suffering of the poor are in the news. Communication by the preacher with his or her church members on this issue is very important. In any case, a prophetic preacher should persevere and must therefore take the long view - a struggle of many years to follow (Tisdale 2010:60-61).

The support of the church is a third condition for prophetic preaching.

\section{Conclusion}

Prophetic preaching should be contextual, building on a biblical theology that is directed to the context of all readers of the Bible, and informed by social analysis (cf. Pieterse 2012b). It also needs contacts and support in the ecumenical faith community. A prophetic preacher must persevere and continue against all odds until the situation is changing for the better.

\section{Acknowledgements Competing interests}

The author declares that he has no financial or personal relationship that may have inappropriately influenced him in writing this article.

\section{References}

Bohren, R., 1974, Predigtlehre, 3rd edn., Kaiser, München.

Buffel, O.A., 2010, 'Journeying with the poor as they struggle for survival and liberation: Pastoral work alongside and together with the poor', Theologia Viatorum: Journal of Theology and Religion in Africa 34(1), 28-48.

Burger, R., Louw, M. \& Van der Watt, C., 2010, 'The challenge of poverty and socia exclusion in post-apartheid South Africa', I. Swart, H. Rocher, S. Green \& J. Erasmus (eds.), Religion and social development in post-apartheid South Africa, pp. 61-73, Sun Press, Stellenbosch.

Claasen, C., 2012, 'Toelaes: ' $n$ Nuwe plan teen geknoei', Beeld, 18 February, p. 7.

Corbett, J., \& Smith, E., 1980, Becoming a prophetic community, John Knox Press, Atlanta.

De Gruchy, J., 1986, Cry justice! Prayers, meditations and readings from South Africa, Collins, London.

De Wet, F.W., 2011, Hoe lieflik is die Lig. ' $n$ Verkenning van die dieptevlak van die homiletiese proses, Potchefstroomse Teologiese Publikasies, Potchefstroom.

Ferreira, L., 2012, '25 000 sake bekyk in bedrog met toelae', Beeld, 23 April, p. 5.

Immink, F.G., 2010, 'Een methode van preekvoorbereiding', in H. Van der Meulen (ed.), Als een leerling leren preken [Learning to preach as a learner], pp. 9-20, Boekencentrum, Zoetermeer.

Laubscher, J., 2012, 'Verwyder struikelblokke wat opwaartse mobiliteit strem', Beeld, Sake24, 5 March, p. 17.

Long, T.G., 2005, The witness of preaching, 2nd edn., Westminster John Knox Press, Louisville, KY

Manala, M.J., 2010, '“A better life for all”: A reality or a pipe-dream? A black theology intervention in conditions of poor service delivery in the democratic South Africa', Scriptura 105, 519-531.

Mandela, N., 2010, Conversations with myself, Macmillan, London.

Manuel, T., 2012, 'Daar ís genoeg geld', Kerkbode, 20 April, p. 1.

Müller, B.A., 1996, 'Profetiese prediking op weg na 2000 plus', in M. Nel (ed.), Prediking: Kommunikasie in konteks, pp. 47-78, Makro Boeke, Pretoria.

Nieuwenhuis, J., 2007, 'Qualitative research designs and data gathering techniques', in K. Marais (ed.), First steps in research, pp. 69-97, Van Schaik Publishers, Pretoria.

Pieterse, H.J.C. (ed.), 2001, Desmond Tutu's Message: A qualitative analysis, Brill, Leiden/ Boston/Köln.

Pieterse, H.J.C., 2004, Preaching in a context of poverty, University of South Africa Press, Pretoria.

Pieterse, H.J.C., 2012a, 'A grounded theory approach to the analysis of sermons on poverty: Congregational projects as social capital', Verbum et Ecclesia 33(1), 689. http://dx.doi.org/10.4102/ve.v33i1.689

Pieterse, H.J.C., 2012b, 'Social analysis of the poverty situation in South Africa revisited', Theologia Viatorum 36(1), 1-22.

Rademeyer, A., 2011, 'SA se gr. 6e vaar swak', Beeld, 5 April, p. 2.

Ricoeur, P., 1976, Interpretation theory: discourse and the surplus of meaning, The Texas Christian University Press, Fort Worth, TX.

Strydom, T., 2009, 'Rykstes word ál meer', Beeld, Sake24, 13 January, p. 1.

Tisdale, L.T., 2010, Prophetic preaching: A pastoral approach, Westminster John Knox Press, Louisville, KY.

Tutu, D., 2011, God is not a Christian: Speaking truth in times of crisis, Rider Books, London/Sydney/Auckland/Johannesburg.

Van Aarde, A.G., 2012, 'The righteousness of God, begging for the poor and Paul's apostolic mission according to his Letter to the Romans', HTS Teologiese Studies/ Theological Studies 68(1), 1223. http://dx.doi.org/10.4102/hts.v68i1.1223

Wepener, C. \& Cilliers, J., 2010, 'Ritual and the generation of social capital in contexts of poverty', in I. Swart, H. Rocher, S. Green, \& J. Erasmus, J. (eds), Religion and socia development in post-apartheid South Africa, pp. 417-430, Sun Press, Stellenbosch.

West, C., 2004, Democracy matters: Winning the fight against imperialism, Penguin Press, New York. 